\title{
The Translator as Agent in Talent Management Knowledge
}

\section{Transfer}

Susanne Tietze

Keele Management School (Darwin Building)

Keele University

Darwin Building

UK Staffordshire, ST5 5BG

Tel: ++44 (0) 1782734279

Email: s.tietze@keele.ac.uk

Carole Tansley

Nottingham Business School

Nottingham Trent University

Burton Street

UK Nottingham NG1 4BU

Tel: ++44 (0) 1158482415

Email: c.tansley@ntu.ac.uk

Emil Helienek

Nottingham Business School

Nottingham Trent University

Burton Street

UK Nottingham

Tel: ++44 (0) 1158488695

Email: e.helienek@ntu.ac.uk 


\begin{abstract}
We investigate the transfer of talent management knowledge into a Slovak manufacturing setting from a translation perspective. The translator is shown to be the key agent in the cross-national, cross-language knowledge transfer process, who not only provides linguistic translation, but also cultural-political interpretation of key vocabularies. By drawing on different approaches to translation we show that a) discourse and language cannot be separated in knowledge transfer interventions and that $b$ ) the translator is a key agent in shaping the cross-culture transfer process by addressing the 'discursive void' that characterises local experiences with, and knowledge about, talent management. We develop understanding about the role of bilingual, bicultural agents in international knowledge transfer.
\end{abstract}

Introduction

Globalisation has been defined as the growth in worldwide interconnection and interdependency at the cultural, political and economic levels (Giddens, 1999). Within a global context, we investigate the transfer of (talent) management knowledge across cultural, national and linguistic boundaries from a translation perspective. This perspective contributes to understanding of cross-cultural knowledge transfer by providing insights into the reception of bodies of knowledge at culturally different locations. Recently, there is an emergent literature in the fields of international management and in cross-cultural management studies, which concerns itself with the role of agents, who have particular cultural and language skills. These agents are referred to as biculturals and bilinguals in the cross-cultural management literature (Brannen and Thomas, 2010; Luna, Ringberg, Peracchio, 2008; Ringberg, Reihlen, Luna \& Peracchio, 2010; Thomas, Brannen and Garcia, 2010) and as either 'language nodes’ 
(Piekkarie, Welch \& Welch, 1999) or more recently as 'boundary spanners' (Barner-Rasmussen, Ehrnroot, Koveshinikov, Mäkelä, 2014; BarnerRasmussen, 2015) in the international management literature. They have now been identified as transmitters of knowledge who are located at the interstices of international knowledge transfer, yet their particular role and contribution is far from being fully understood. In this paper we therefore offer more insight into the particular role that such located agents provide and in particular how they wield their bicultural and bilingual minds and skills in particular moments of international knowledge transfer. This paper therefore develops the existing insights of these papers by providing evidence that the historical-cultural cognitive -map of a particular translating agent is intrinsically linked to the agent's language skills, which comprises of high level of competence in English (the lingua franca used in the investigated scenario) and native speaker competence in the local language, Slovak. It is the combination of these skills, professional expertise and a particular mindset that enables agency to unfold and enables knowledge transfer, or knowledge translation.

In this paper we use the example of talent management as a particular body of knowledge and practice and show how it becomes translated into a Slovak manufacturing setting. Talent management is an English language-based discourse originating in the US consultancy industry and this point of origin is culturally, politically and historically, as well as linguistically, quite different from the point of reception. We capture this 'difference' through the vocabulary 
of 'discursive void', which we define as the 'lack of' a linguistic signification system (a language) that enables the recipient audience (company senior managers and executives) to make sense of the discursive content of the talent management discourse.

We draw attention to the lasting influence of political-historical legacies when talent management is introduced into a new setting, and by focusing on the introductory event of talent management, we highlight the agency exercised by the individuals involved in the transfer process (a consultant and a translator). In this multilingual case study context, the translator is established as an active agent in this process. This is important because, to date, the role of translators as important knowledge brokers is unacknowledged, under-explored and undertheorised (Susam-Saraeva \& Perez-Gonzalez, 2012). Finally, we contribute to understanding of the translator as a cross-cultural, cross-language agent by demonstrating how agency unfolds through simultaneous cultural and linguistic translation work.

In describing talent management as a discourse, we show how it is intrinsically linked to the English language, and thus its transportation into a different linguistic-discursive environment (here the Slovak Republic) requires translation. From thereon we briefly sketch out the discursive environment in terms of Western management knowledge in some Central and Eastern European countries since the period of post-communist transition and introduce the notions of discursive void, semantic void and discursive hazard. We then turn to the Slovak Republic as the country case setting and to the organizational setting, 'The 
Welding Company’. We continue to discuss in detail the methodology, research design and data analysis, before proceeding to discuss findings and theorise how 'discursive void' can be addressed through translation if understood as linguistic, cultural and political acts of recontextualisation.

Talent Management as Discourse

In following Holden and Vaiman's call for 'studies into contrasting ways of transferring talent management concepts and practices' (2013, p. 142), we treat talent management as a discourse, by which we mean organized systems of meaning in which sets of connected concepts, terms, statement and expressions constitute a way of thinking and communicating about a particular item, theme or issue, which provides a guiding trajectory for the ways people feel, respond to and enact it and which provides 'discursive resources' such as technical vocabulary and metaphors to do so (Watson, 1995).

While talent management discourse continues to change and develop, some of its root vocabulary is firmly established. For example, its root metaphor of 'the war for talent' was coined in the late 1990s by a group of McKinsey consultants (Chambers, Foulton, Handfield-Jones, Hankins \& Michaels, 1998; Michaels, Handfield-Jones \& Axelrod, 2001) to express the central importance of top performing employees for sustainable organisational performance; the recognition of leadership development, coaching and mentoring and so on. 
With global talent management becoming more central to academic interest, recent foci have shifted onto comparative studies, which consider how talent management is received, interpreted and treated in different national contexts and cultures (McDonnell, Ryan, Gunnigle \& Lavelle, 2010; Tansley, 2011; Tansley, Tietze \& Kirk, 2013). Scholars point out the lack of studies of non-Western settings and locations (Al Ariss, Cascio \& Paauwe, 2014; Meyers \& van Woerkom, 2014). Despite this emergent interest in the travel, adoption and embedding of talent management discursive practices in 'other' localities, the majority of academic articles remains largely reflective of the Anglo-Saxon (i.e. US or UK) business context (Dries, 2013) and do not provide grounded details about the unavoidable translation process which accompanies the travel of discourse-knowledge across boundaries. As the empirical case study of this paper is located in 'another' setting, i.e. the Slovak Republic, a newly founded nation state (1993) in Eastern Europe, we now discuss the 'discursive environment' of the transforming Central and Eastern European states, before we provide more details about the specific historical-political context of the Slovak Republic as well as the case setting.

The discursive environment in Central and Eastern Europe

The late 1980s and early 1990s saw major historical-political events such as the fall of the Berlin Wall in 1989 and the collapse of the Soviet Union by 1991. These events heralded the end of the 'cold war period' and the change from 
centrally planned economies to (free) market based economies for most Eastern and Central European countries. The collapse of state socialism across this huge region continues to pose questions about 'how these societies, their industries and their enterprises could become integrated into the global economic context, following their many decades of relative isolation’ (Soulsby \& Clark, 2007, p. 1420).

Most commentators agree that countries developed different trajectories in how transformation was received and implemented, that the adoption of modern management knowledge, 'cannot be isolated from broader societal issues' (Hollinshead, 2010, p. 174) and that 'socialist legacies’ (Holden \& Vaiman, 2011; Holden, Fink \& Kuznetsova, 2008) continue to exist. Introducing concepts and practices from modern management knowledge, initially by a stream of Western consultants and advisers, remains problematic as many key terms and ideas are imbued with meaning systems from the Soviet legacy. For example, the notion of leadership, a central concept in Western management knowledge and also in the practice of talent management, remains strongly associated with the rule of Communist Party and 'any concept of talent [leadership talent] was subordinated to political requirements in loyalty to the Party ... 'Talent' had to be seen to be literally politically correct” (Vaiman \& Holden, 2011, p. 21). Those with the politically correct attitudes and commitment formed the nomenclatura, the exclusive talent pool which served as 'a magic circle of top bosses'. Thus, talking of leadership in these contexts evokes different meaning systems (whether a loan word or not is used), which are quite different from the associations of 
leadership with self-directed behaviour and values of individual achievement, which are the normative assumptions upon which talent management was originally based upon.

\section{A Lack of Meaning and Practice: Semantic Void}

The lack of exposure to, and experience with, the discourses and practices of the market economy and management practices in transitional economies has been referred to as 'semantic void'. Holden et al. (2008) show Russia to be affected by 'semantic void' as the Russian language held no vocabulary to express market economy concepts and functions, so that a term such as 'knowledge management' cannot be directly translated as there is no 'equivalence' of meaning. Tracking the translation process of a book on knowledge management from English into the Russian language, Holden et al. (2008, p. 121) show how this task 'defeated the translator' requiring many explanatory footnotes, not just for the expression 'knowledge management', but also for related vocabulary and practices. In other words, the term knowledge management only make sense in contexts where knowledge is deemed to be a competitive resource, that can be collected, systematised, presented and organised in particular ways. In the Russian context in the mid 1990s, the domestic language (Russian) could not adequately convey Western terminology; consequently, the phenomena described could not be correctly identified and explained (Holden et al. 2008). 


\section{Knowledge Transfer and Discourse Void}

Kuznetsov and Kuznetsova (2014) comment on the impact of discursive factors on trans-border exchange of expertise and competence in the context of former Soviet republics and argue that these will continue to play an important part in the transfer of management knowledge and its use for the benefit of companies and individual agents. They refer to a 'discursive hazard' for Western companies that seek location and contacts in Eastern European countries due to the 'lexical deficit' they will meet with. According to these scholars, translation issues still impact heavily on the transfer of Western management knowledge and ideas even after two decades of modern business knowledge influx e.g. marketing is still 'an ordeal', as even a 'correctly transmitted message' does not yet constitute knowledge, because it relies on mental models, beliefs, deep discursive knowledge to take root and make sense.

This is particularly so for talent management as it is a till a relatively new and developing discourse with expanding vocabulary and categories (Cerdin \& Brewster, 2014; Vaiman \& Haslberger, 2013). Accordingly, there is limited available empirical evidence of how talent management is received in Central and Eastern European countries (Skuza, Scullion \& McDonnel, 2012 on Poland; Vaiman \& Holden, 2011 and Holden \& Vaiman, 2013 on Russia). Yet from these sources it is clear that its introduction and adoption in Central and Eastern European countries is still characterised by the relatively high discursive hazard as very basic terms such as 'openness', 'development' or 'mentoring' do not 'translate' easily as they are not rooted in accompanying experiential and 
discursive systems. Even if used as direct loan words, they do not convey equivalent meaning. For example, ‘mentoring’ describes work-based relationships between senior and junior staff and is based on values such as openness and trust. Vaiman and Holden (2013, p. 1310) contend that talent management is yet another western management concept that is only partially understood in Russia. This 'partial' understanding is not explainable by a general lack of ability of the recipient audience to engage with and intellectually grasp the notion of talent management, but with: 'Notions of empowerment or the self-driven employee are quite central to the assumptive basis of talent management discourse - yet, [they] do not exist in Russia, neither as an equivalent word or concept to express them, nor as a related word or idiom to explain them' (Holden \& Vaiman, 2013, p. 134). This is because acting in an 'empowered' way, for example, would not only have been inappropriate in Russian context, it may well have been too dangerous to do so.

The transition of former planned economies to market economies was facilitated through the import of management concept and practices (i.e. discourses) through the providers of management knowledge, e.g. Western consultants and management academics. A general assumption about how cross -national and cross-lingual knowledge transfer happens is that knowledge systems 'travel easily' as they are 'carried through a shared lingua franca', i.e. the English language. Yet, despite the dominance of the English language as a lingua franca of international business and management and its widespread use in particular amongst business/management elites and leaders (Tietze, 2004), it cannot be 
assumed that the vocabulary of talent management, which is expressed in English, is easily understandable to a non-English speaking audience, even if translated or even if loan words are used.

In the light of the above discussion, however, it becomes clear that words, concepts and practices have cultural and political contexts as well as historical roots; these inform the reception of discursive knowledge and practice.

Translation is not a mechanical act of reception, replacing one word from the source language with another word from the target language; rather it comprises of ongoing acts of cultural, political, historical engagement. Discursive void then refers to deficiency within a language to reflect and express particular experiences and bodies of knowledge originating from another language. Discursive void is both a lack of 'language' and a lack of ‘discourse and experience in a given field of knowledge and practice'. In this regard, the agency of the translator can be understood as an activation of plural linguistic and cultural mindsets with a view to address and fill this discursive void.

TABLE 1 ABOUT HERE: SUMMARY OF MANAGEMENT CONCEPTS AND MEANINGS IN CENTRAL AND EASTERN EUROPEAN CONTEXTS

The case setting

The new Slovak Republic came into existence as an independent nation state on the 1st January 1993, following the 'velvet divorce', i.e. a peaceful division of Czechoslovakia into two succession states - the Czech Republic and the Slovak 
Republic. The Slovak Republic joined the OECD in 2000 and the EU in 2004, the Euro has replaced the Slovak Koruna on 1st January 2009. Czechoslovakia has achieved a high stage of industrialisation in the 20th Century. Between the First and Second World Wars Czechoslovakia was one of the top ten most industrialised nations in the world.

There was increased industrialisation in Slovakia under communist governments in the latter half of the 20th century. Heavy machinery and armament industry become an important branch of industrial development in Slovakia. Following the collapse of communism, there was decline in this industry, yet signs of recovery were recorded since the Slovak independence. Since then, the Slovak Republic has become one of the biggest car producers per head in the whole world. The world's leading car companies have invested heavily in Slovakia (i.e. Volkswagen, Peugeot-Citroen and KIA).

The national language is Slovak (spoken by about 5.3 million Slovaks and a further 0.5 million mainly in the US and Canada), with English being increasingly used by the young generation as the language of business, while German is still more commonly used in particular by an older generation.

The case company (the Welding Company) specialises in advanced forms of welding and it is in a small town in the southern-central Slovakia, with a population of circa 15,000, where a factory for manufacturing heavy machinery was founded in 1955. In its heyday, the Welding Company, employed 6,500 staff, but had to downsize to 560 by 2009. By 2012 the number of employees had risen 
to 1400 . The company's current development is described as the 'new era', that is characterised by a stronger sense of strategic direction, internationalisation (through a change in ownership structures; international customers and influx of international senior staff) and a new emphasis on developing the attitudes and mindsets of all staff, but in particular of senior management. This new area is led by the chief executive officer, a Slovak native, educated (in English) to MBA (Master of Business Administration) level, whose vision for the Welding Company is to create a 'permanently dynamic, modern and internationally recognised company providing services in their production of welded components' (presentation by the chief executive officer, 2012). Its core manufacturing programme includes complex welded components for a variety of industries and sectors and its customer base includes international companies like Atlas Copco, Komatsu, Volvo, John Deere, Caterpillar and others.

The pressure on the chief executive officer to improve economic performance and to create a 'modern company' had been immense since an influx of foreign capital provided the financial bedrock for the Welding Company. The 'new era' is thus associated with fierce economic competition; an influx of senior staff with different nationalities, which has increased language diversity amongst senior decision makers. The company language remains Slovak, but executives are increasingly expected to be able to communicate in English. Some managers of the younger generation have some competence in the English language. 


\section{Methodology}

To date there is only limited engagement of international business scholars with issues arising from cross-language research (for exceptions see Welch \& Piekkari, 2006; Xian, 2008) beyond following protocols for back translation (cf. Brislin, 1970). There are no sophisticated existing protocols or methods for capturing and reporting 'linguistic and translation data', nor how to analyse and theorise it. The role of translation as a necessary, but hidden practice in global processes exercised by 'normal' employees, managers or other agents of international networks (Piekkari \& Tietze, 2014; Barner-Rasmussen \& Aario, 2011), and the role of translation theory as a conceptual-analytical trajectory are yet to be fully developed by cross-cultural and international management scholars (some exceptions are Steyaert \& Janssens, 2013 and Chidlow et al. 2014). Likewise, within translation studies, attention has only just begun to focus on the role of non-professional translators/interpreters as ‘a distinct phenomenon’ (SusamSaraeva \& Perez Gonzales, 2012, p. 149), providing insights into processes of global transactions.

Taking this lack of tradition in using translation as a topic to be explored or as an analytical tool, we locate it in a hermeneutic tradition, focusing on understanding ('verstehen') a phenomenon from different perspectives (McAuley, Duberley \& Johnson, 2007). This approach also entails paying attention to historical, political and socio-economic contexts within which interpretation is produced. The perspectives we pertain to understand are that of the translator (who both translated and interpreted) during a 'talent management knowledge transfer 
intervention' as the key agent in enabling and shaping the knowledge transfer; we also consider the role of the consultant, an expert in talent management, both in terms of consultancy and academic experience. This research account is the outcome of a three-way conversation between the translator, the consultant and the researcher and the mindsets in particular of the translator and the consultant are presented below (table 2) their difference explains their different interactions with the case study company. Data generated is from this particular intervention (a two day workshop on talent management, delivered at the company itself) and it provides a snapshot of the transfer of management knowledge. It is not intended to provide commentary on events or developments after the workshop.

\section{Data generation}

The author interviewed the consultant, who is a native speaker of English and has had some experience with delivering management development programmes in the Czech Republic, and the translator, a Slovak national and speaker of Slovak and English, given that he works in the UK as an international business academic. He is neither a professionally trained translator nor an interpreter, yet his involvement was central to the unfolding interactions. The main author is a bilingual (German/English) academic with particular training in linguistics and translation and personal and professional experience of the transition process form a German perspective, but no significant understanding of the Slovak language and history. 
The first interview was held with the consultant and the translator together to work through the experience and genesis of the knowledge transfer intervention. This was followed by several separate interviews with each, focusing on the establishment of the context and purpose of the talent management interventions, and a discussion of the dynamics of the intervention itself. Here, a further interview with the translator was used to establish difficulties of translating English language materials: a detailed pack comprising 100 pages had been compiled by the consultant and was initially translated by a professional translation agency, using a software package; this was followed by amendments made by one of their professional translators before it was passed on to the translator, who corrected yet again words, meanings and expression as he was troubled by the many mistakes he found in the materials. He became increasingly aware of the underlying complexities of this enormous task (Interview 2). The translator also acted as interpreter during the workshop as the audience comprised senior managers and executives, of which the CEO and a Swiss executive had excellent English, the human resource and marketing directors had some English and the directors of production had no English. The workshop was also attended by other senior role holders, including the finance director and accounts managers.

The third interview with the translator comprised a detailed discussion of the provided English language materials and how they were translated. These English language materials were available and are therefore also treated as data and 
included in the analysis. Furthermore, the Welding Company operates an English-language webpage which was accessed and informed our understanding of the scope and character of the Welding Company. Access to presentation materials by the CEO were also made available and used in the same way.

TABLE THREE ABOUT HERE

\section{UNTRANSLATABLE OR PROBLEMATIC WORDS AND CONCEPTS FROM THE EMPIRICAL STUDY}

\section{Data analysis}

Data analysis comprised two steps. Step one entailed the categorisation of data following the translation modes developed by Janssens, Lambert and Steyaert (2004) who develop translation strategies based on different epistemological assumptions about language. The mechanical model assumes that there is complete or almost complete equivalence between words and concepts in different languages. The cultural model sees translators as a traveller between different worlds and translating entails the recontextualisation of words, meanings and practices with the aim to achieve intelligibility in the target text/target location. The political model focuses on power relationships between different agents, locations and languages. This categorisation provided a mechanism to establish the purpose of the translation/interpretation effort by the translator. Analysis also involved working several times through the data (together with the translator) to 
establish the different meanings allocated to key vocabulary from the talent management and establish with aspects of talent management were difficult or non-translatable.

\section{Findings}

The mechanical approach to understanding translation by finding equivalent words and meanings clearly did not provide intelligibility for the target audience. The services provided by the translation agency (both machine and non-machine translation) were therefore insufficient to ensure that the talent management discourse was meaningfully received. On every page of the materials there were mistakes, which rendered much of the materials 'gobbledegook' (Interview 2 with translator). This cannot be attributed to ‘bad or poor translation’ as Holden et al. (2008) point out, but it shows the lack of an established discursive system in the Slovak language which would enable the translator to find (near) equivalent expressions; it also points to the existence of discursive void.

The Translator frequently used English loan words for key vocabulary and concepts; yet the use of these loan words did not resolve his dilemma that the meaning attached to these loan words remained Slovak. For example, 'talent' evokes associations of being artistically gifted (Interview 2, Translator) rather than being directly associated with a professional discourse and an approach to managing personnel. Other terms such as 'leadership', 'leadership development' and ‘training and mentoring' were also frequently used as loan words. Yet, the 
translator was highly aware of deeply rooted differences in the meaning of these words and provided (in particular during the workshop) explanations with a view to counteracting existing assumption about leadership being automatically autocratic and hierarchical; or that training is, unless it relates directly to tasks at hand, a waste of time, or possibly even assumed to be corrupt as funds are channelled into commissioning agents pockets (Interview 3, the translator).

The relative length of his interventions during the workshop as compared to the consultant's interventions - noted and commented on by both (see table 2) originates from the historical-political context of the company and intervention being situated in it; a context which necessitated additional explanation of many terms, whether used as loan words or not (see tables 2 and 3). There were instances in the training materials relating to 4 different types of leadership/talent categories (leadership talent, key talent, core talent and peripheral talent), which were presented in a pyramid, indicating their relative importance for an organisation (see table 3). The translator commented (Interview 3):

(...) the main problem stems from four types of talent in the pyramid. This makes it difficult to explain the subtle differences between core and key talent and perhaps also leadership talent. In Slovak mind leadership talent is also automatically a key and core talent. (...) there is the word 'kluchovy talent' [for 'key talent' - the Author], but the same Slovak word you will use for core talent and in Slovak mind and culture leadership talent is also a core talent and so on'. In this instance the Translator had to deal with the existence of differentiated categories of leadership/talent for which no equivalence could be found, as it did not exist. In order to render these categories meaningful, the translator expanded his input and explained how these two words were related to particular 
organizational structures; yet his difficulty in doing this related to the lack of preknowledge and little or no English competence (i.e. discursive void) in the audience. Much of the work of the Translator was that of a cultural sense-maker and politically aware agent. His inputs included initial linguistic translation, but this translation needed to be elaborated on and made relevant in the context of participants. Elaboration sometimes included adding on an example to provide a meaningful illustration of how a supervisor could use aspects of the talent management to manage a work problem with motivation: they need to know what to do with a drunken Joe who turns up on a Monday morning and how to make him do a good welding job. The translator addressed these issues by translating examples from the workshop materials and by providing additional material in order to recontextualise this knowledge. These added examples, explanations and elaborations fall under the cultural model as they imply mediation between different linguistic and cultural words. Legacies of the previous political system were referred to frequently by the translator who pointed out that (Western) management consultants in the early transitional years were understood in some central and eastern European countries as dangerous and hypocritical frauds (Interview 1) and that his translation and interpretation work was conducted through the historical lens of communism, i.e. a sense of history and politics which framed his understanding of the workshop and its participants.

Discussion: Filling discursive void through translation

We have defined 'discursive void' as being a void of language (here: English) as well as a void of associated meaning systems (discourse: here talent management) 
which has roots in experience and provides trajectories for action. Thus, discursive void refers to two related phenomena: language and discourse, which form an inseparable whole. This nexus of ties between language and discourse is at the core of the 'knowledge translation process'. In line with the cross-cultural management literature on the role of bilinguals and biculturals in international work contexts, we found that cultural frames are activated when using particular key words or expressions from another language (see Ringbert et al., 2010; Hong et al., 2000). In other words, 'language triggers frame switching among biculturalbilinguals and [that] this process is largely tacit' (Ringberg et al., 2010, p. 77). By focusing in this paper on the translation process itself and also on the agency of this particular bicultural-bilingual individual (the translator), we have provided empirical examples about how the articulation of what remains usually a tacit process, is de facto the fundamental necessity of cross-language, cross-cultural knowledge transfer.

Findings show that translation work is knowledge translation work, which starts with linguistic translation and includes cultural and political aspects of concepts and ideas. Knowledge translation work includes situated, agentic interventions. Loan words are a wide-spread mechanism to transfer concepts from a 'foreign' into the new setting, yet their use also points to discursive void when they are only used if no local equivalent or even 'near equivalent' concepts exist. In this regard the use of loan words fills the discursive void to only to a limited extent. They can also be a means of just glossing over discursive void, not least if they are used in an unreflective way, as was the case during the early transitional years when 
Western consultants acted as the main knowledge brokers (Kostera, 1995;

Hollinshead \& Michailova, 2001). In this case example, however, we show that the translator was fully aware that using a loan word does not enable the audience to comprehend the culturally different meaning attached to it. Rather, than just using the word talent management as a loan word, he was able to qualify its meaning so that it became more relevant for the audience. This was achieved through simultaneous cultural and linguistic switching of frames between English and Slovak on the language level and at the same time between historical, political, cultural norms and assumptions.

Discursive void cannot be addressed through models of translation which are based on equivalence; though the existence of 'equivalence' appears to be the unacknowledged assumptions of the providers of management knowledge, i.e. that the English language is the universal language of all management experience and knowledge. This case study provides evidence that the existence of multiple languages is reflective and expressive of multiple and diverse experiences. Neither the use of loan words nor the mechanical replacing of words address the discursive void. Yet it can be filled through creative translation, where through enormous and exhaustive enterprise (interview 2 with the translator), which include the invention of examples, the deliberate and context-sensitive change of words and ideas. 
The filling of discursive void, then, is achieved through translation, employing loan words, the elaboration of examples and stories as well as the invention of examples, i.e. a strategy which is based on a cultural translation approach. Yet, this cultural translation invokes the historical-political contexts (translating through the prism of communism) and political translation effort relates to the translator's awareness of particular (negatively connoted) notion of leadership, the role of management consultants and the use of training and development budgets; so, that much of the translation activity was done to create a counter-balance to preconceived perceptions and perspectives.

Conclusion: Translated into being

Translation is an important part of cross-cultural knowledge transfer and future studies need to treat it as an agentic aspect of knowledge transfer, indeed we propose to use the term knowledge translation instead: Translation has to be done by someone: These ‘someones’ are polylingual, culturally- and politically-situated actors. Their acts are fundamental to the production of 'new' realities which are 'translated into being'. The focus of this paper is on the new demographic (Brannen and Thomas, 2010) of non-professional translators and interpreters, i.e. people who are located, by role or by happenstance at the very intersections of cultural and linguistically different world. The process of aligning these worlds has been shown as being normally quite tacit and habituated. Yet, the contribution of these translating knowledge brokers lies in their ability to render thes 
e processes explicit to themselves and their respective audiences. We concur therefore with Ringberg et al's. (2010) observation that these bicultural-bilingual mediators (or translators) require training in order to realise their ability to switch culture and language frames and 'to make them cognizant of their [own] tacit cognitive process'. A process that the translator in this study came to realise through the enormity of the task he was involved in. The work and influence of these situated translators and their roles in multinational organizations and in other international work contexts is not yet fully understood. Contributions in the field of international management (Barner-Rasmussen et al., 2014; BarnerRasmussen, 2015) have shown translators to be boundary spanners, who through their cultural and language skills link, facilitate and intervene in international work contexts. Barner-Rasmussen points to their potential as consensus building creators, who 'leverage their linguistic and cultural savvy by interpreting and managing not only their own responses but also those of others nearby, thus helping to frame day-to-day interaction in consensual terms' (2015, p. 145). As fields of inquiry, both cross-cultural management and international management scholars have some way to go to identify and understand this invisible work of agents at the interstices of the global epoch. Likewise, international organisations must develop mechanism to capture, appreciate and train these bilingual, bicultural translator-mediators to alleviate some of the difficulties and frustrations that accompany international collaborations. 
The meeting of languages and therefore translation warrant particular attention in the current historical epoch of globalisation; this includes a consideration of the role of English in cross-cultural, cross-border knowledge transfer, but also the role of translation at the receiving location. Scholars have responded to multicultural realities by developing tools to examine phenomena from cross-cultural perspectives. In complementing these established approaches, a turn to translation studies offers a multitude of approaches and theories to inform the understanding and formation of cross-cultural knowledge transfer realities. An example may be further inquiry into the use of loan words, their reception and interpretation in particular settings. From a cross-cultural management perspective, understanding the process of translation in more detail, is therefore a promising trajectory for future projects. Despite the limitation of this study in terms of scale and scope, the focus on the agency of the translator and the continued influence of historicalpolitical factors have opened up a less explored avenue for future inquiry.

\section{REFERENCES}

Al Ariss, A., Cascio, W.F. \& Paauwe, J. (2014). Talent management: Current theories and future research directions. Journal of World Business, 49, 173 - 179.

Barner-Rasmussen, W. \& Aarnio, C. (2011). Shifting the faultlines of language: a quantitative functional-level exploration of language use in MNC subsidiaries. Journal of World Business, 46, 288 - 295.

Barner-Rasmussen, W., Ehrnrooth, M., Koveshnikov, A. and Makela, K. (2014). Cultural and language skills as resources for boundary spanning within MNC. Journal of International Business Studies, 45, 7, 886 - 905. 
Barner-Rasmussen, W. (2015) 'What do bicultural-bilinguals do in multinational corporations?' in: Holden, N., Michailova, S. and Tietze, S. (eds). The Routledge Companion to Cross-Cultural Management, pp. 142 - 150.

Brannen, MY and Thomas, D.C. (2010). Bicultural individuals in organizations. Implications and opportunity. International Journal of Cross Cultural Management. 10, 1, 5- 16.

Brislin, R.W. (1970). Back-translation for cross-cultural research. Journal of Cross-Cultural Psychology, 1, 185 - 216.

Cerdin, J-L., \& Brewster, C. (2014). Talent management and expatriation: Bridging two streams of research and practice. Journal of World Business, 49, 245 $-252$.

Chambers, E.G., Foulton, M., Handfield-Jones, H, Hankin, S.M. \& Michaels, E.G. III (1998). The war for talent, McKinsey Quarterly, 3, 44 - 57.

Chidlow, A. , Plakoyiannaki, E. and Welch, C. (2014) Translation in crosslanguage international business research: beyond equivalence. Journal of International Business Studies, 45, 5, 562 - 582.

Dries, N. (2013). The psychology of talent management: A review and research agenda. Human Resource Management Review, 23(4): 272 - 285.

Giddens, A. (1999). Runaway world: how globalisation is reshaping our lives. London: Profile Books.

Holden, N., Kuznetsova, O. \& Fink, G. (2008). Russia's long struggle with Western terms of management and the concepts behind them. In S. Tietze (Ed.), International management and language (pp.114 - 127). London: Routledge.

Holden, N. \& Vaiman, V. (2013). Talent management in Russia: not so much war for talent as wariness of talent. Critical Perspectives on International Business, 9, $129-146$.

Hollinshead, G. (2010). International and comparative HRM. McGraw-Hill.

Hollinshead, G. \& S Michailova, S. (2001). Blockbusters or bride-builders? The role of Western trainers in developing new entrepreneurialism in Eastern Europe. Management Learning, 32, 419 - 436.

Hong, Y-Y., Morris, M.W., Chiu C-Y., Benet-Martinez, V (2000). Multicultural minds. A dynamic constructivist approach to culture and cognition. American Psychologist, 55,7, 709 - 720. 
Janssens, M., Lambert, J. \& Steyeaert, C. (2004). Developing language strategies for international companies: the contribution of translation studies. Journal of World Business, 39, $414-430$.

Kostera, M. (1995). The modern crusade. The missionaries of management come to Eastern Europe. Management Learning, 26, 331 - 362.

Kuznetsov, A. \& Kuznetsova, O. (2014). Building professional discourse in emerging markets: language, context and the challenge of sensemaking. Journal of International Business Studies, 45, 5, 583 - 599..

Luna, D., ringerg, T and Peracchio, L. (2008). One individual, two identities: frame switching among biculturals. Journal of Consumer Research, 35, 279 293.

McAuley, J., Duberley, J. \& Johnson, P. (2007). Organization theory. Challenges and perspectives. Harlow, UK: Pearson Education Limited.

Michaels, E. G. III, Handfield-Jones, H. \& Axelrod, B. (2001). The war for talent. Boston, MA: Harvard Business School Press.

Montgomery, S.L. (2013). Does science need a global language? English and the future of research. Chicago and London: The University of Chicago Press.

Piekkari, R., Welch, D.E., Welch, L.S., Peltonen, J-P. \& Vesa, T. (2013). Translation behaviour: an exploratory study within a service multinational. International Business Review, 22,771 - 783.

Ringberg, T.V., Luna, D., Reihlen, M. and Peracchio, L. (2010). Biculturalbilinguals. The effect of cultural frame switching on translation equivalence. International Journal of Cross cultural Management, 10,1, 77 - 92.

Skuza, A., Scullion, H. \& McDonnell, A. (2012). An analysis of the talent management challenges in a post-communist country: the case of Poland. The International Journal of Human Resource Management, 1, 1 - 18.

Soulsby, A. \& Clark, E. (2007). Organization theory and the post-socialist transformation: contributions to organizational knowledge. Human Relations, 60, $1419-1442$.

Steyaert, C. \& Janssens, M. (2013). Multilingual scholarship and the paradox of translation and language in management and organization studies. Organization, 20, $131-142$.

Susam-Saraeva, S. \& Perez-Gonzales, L. (2012). Non-professional translating and interpreting. The Translator, 18, $149-166$. 
Tansley, C. (2011). What do we mean by the term 'talent' in talent management? Industrial and Commercial Training, 43(5): 266 - 274.

Tansley, C., Kirk, S. \& Tietze, S. (2013). The currency of talent management. A reply to "talent management and the relevance of context. Towards a pluralistic approach”. Human Resource Management Review, 23(4): 337 - 340.

Thomas, D.C. Brannen MY, Garcia, D. (2010). Bicultural individuals and intercultural effectiveness. European Journal Cross-Cultural Competence and Management, 1,4, pp. 315 - 333.

Tietze, S. (2004). Spreading the management gospel - in English. Language and Intercultural Communication, 4, 175 - 189.

Tietze, S. (2010). International managers as translators. European Journal of International Management, 4(2): 184 - 199.

Vaiman, V. \& Holden, N. (2011). Talent management in central and eastern Europe: challenges and trends. In D. Collings \& H. Scullion (Eds.) Smart talent management: building knowledge assets for competitive advantage (pp. 1 - 15), Cheltenham: Edward Elgar.

Vaiman, V. \& Haslberger, A.( 2013). (Eds.) Talent management of self-initiated expatriates: a neglected source of global talent. London: Palgrave MacMillan.

Watson, T.J. (1995). Rhetoric, discourse and argument in organizational sensemaking: a reflexive tale. Organization Studies, 16(5): 805 - 820.

Welch, C. \& Piekkari, R. (2006). Crossing language boundaries: qualitative interviewing in international business. Management International Review, 46, 417 $-437$.

Xian, H. (2008). Lost in translation? Language, culture and the roles of translator in cross-cultural management research. Qualitative Research in Organizations and Management, 3, 231 - 245.

www.slovak-republic.org accessed 3 March 2014 
TABLE 1: SUMMARY OF KEY MANAGEMENT CONCEPTS AND THEIR MEANINGS (as based on Vaiman \& Holden, 2011; Holden \& Vaiman, 2013; Holden, Kuznetsova \& Fink, 2008; Skuza et al., 2012)

\begin{tabular}{|c|c|c|}
\hline KEY TERM & Meaning: Anglo Saxon & Meaning: CEE \\
\hline Leadership/talent & $\begin{array}{l}\text { Individualistic, self- } \\
\text { driven, communicating } \\
\text { unifying vision and } \\
\text { purpose; related to the } \\
\text { individualistic notion of } \\
\text { the (self) empowerment. }\end{array}$ & $\begin{array}{l}\text { 'entrenched } \\
\text { bossdom' = } \\
\text { combination of } \\
\text { authoritarianism } \\
\text { with paternalism; } \\
\text { politically correct, } \\
\text { nomenklatura as } \\
\text { ideologically } \\
\text { sanctioned 'talent } \\
\text { pool'. }\end{array}$ \\
\hline Talent Management & $\begin{array}{l}\text { Gifted; established as part } \\
\text { of a particular approach to } \\
\text { manage global resources. }\end{array}$ & $\begin{array}{l}\text { Gifted; artistic; less } \\
\text { well established as } \\
\text { part of a particular } \\
\text { discourse. }\end{array}$ \\
\hline $\begin{array}{l}\text { Development/Mentoring/ } \\
\text { Coaching }\end{array}$ & $\begin{array}{l}\text { Stronger emphasis on } \\
\text { developmental aspects and } \\
\text { empowerment; soft skills; } \\
\text { based on trust in } \\
\text { individual and institution. }\end{array}$ & $\begin{array}{l}\text { Stronger emphasis } \\
\text { on technical, on the } \\
\text { job training; 'soft } \\
\text { skills are low value'. } \\
\text { Mistrust off } \\
\text { institutions and } \\
\text { people on top } \\
\text { (apparatchik). }\end{array}$ \\
\hline Performance (managerial) & $\begin{array}{l}\text { Based on communication } \\
\text { skills, sense of } \\
\text { entrepreneurship, } \\
\text { flexibility. }\end{array}$ & $\begin{array}{l}\text { Based on technical } \\
\text { expertise. }\end{array}$ \\
\hline Knowledge Management & $\begin{array}{l}\text { Systematic collection and } \\
\text { management of data, } \\
\text { information and } \\
\text { differentiation between } \\
\text { different forms of } \\
\text { knowledge (e.g. tacit, } \\
\text { explicit). }\end{array}$ & $\begin{array}{l}\text { No equivalent word } \\
\text { or directly relevant } \\
\text { meaning system; } \\
\text { leading to non- } \\
\text { sensical translation. }\end{array}$ \\
\hline Evaluation of performance & $\begin{array}{l}\text { Focus on longer-term, } \\
\text { strategic goals. }\end{array}$ & $\begin{array}{l}\text { Focus on short term } \\
\text { goals and } \\
\text { operational tasks. }\end{array}$ \\
\hline
\end{tabular}


TABLE 2: FRAMES OF CONSULTANT AND TRANSLATOR

\begin{tabular}{|c|c|c|}
\hline & CONSULTANT & TRANSLATOR \\
\hline $\begin{array}{l}\text { Experience with } \\
\text { historical- } \\
\text { political context }\end{array}$ & $\begin{array}{l}\text { Some degree of sensitivity as } \\
\text { there had been involvement } \\
\text { with management } \\
\text { development programmes in } \\
\text { Czech Republic. }\end{array}$ & $\begin{array}{l}\text { Deep and lived experience of } \\
\text { transition process and } \\
\text { witnessing the emergence of } \\
\text { the SR. }\end{array}$ \\
\hline $\begin{array}{l}\text { Knowledge of } \\
\text { Company and } \\
\text { Region }\end{array}$ & $\begin{array}{l}\text { Little; the preparation for the } \\
\text { talent management } \\
\text { intervention entailed the } \\
\text { detailed preparation of } \\
\text { materials; little knowledge of } \\
\text { workforce, contexts, location. }\end{array}$ & $\begin{array}{l}\text { Deep and personal } \\
\text { involvement between CEO } \\
\text { and Translator; rich } \\
\text { knowledge of company } \\
\text { context and situation. }\end{array}$ \\
\hline Languages & English & $\begin{array}{l}\text { Slovak and seven other } \\
\text { languages, including English } \\
\text { as 'second mother tongue' and } \\
\text { professional language. }\end{array}$ \\
\hline $\begin{array}{l}\text { Assumption } \\
\text { about } \\
\text { Knowledge } \\
\text { transfer }\end{array}$ & $\begin{array}{l}\text { Based on narrative order of } \\
\text { presenting big ideas, concepts, } \\
\text { benchmarking stories and } \\
\text { examples/applications. } \\
\text { Plenty of materials are } \\
\text { provided as part of service } \\
\text { delivery, so that clients can } \\
\text { 'take away' materials. } \\
\text { Conceptually driven by } \\
\text { 'knowledgability' = } \\
\text { knowledge in contextual use. }\end{array}$ & $\begin{array}{l}\text { Based on assumptions that } \\
\text { knowledge needs to be direct } \\
\text { and practical. } \\
\text { Service to client is based on } \\
\text { in-depth discussion of all } \\
\text { materials. } \\
\text { Driven by awareness of how } \\
\text { much is at stake for the } \\
\text { CEO/company and far } \\
\text { reaching and continued impact } \\
\text { of world, national and local } \\
\text { history. }\end{array}$ \\
\hline $\begin{array}{l}\text { Engagement } \\
\text { with Audience } \\
\text { and Context }\end{array}$ & $\begin{array}{l}\text { Mediated through the } \\
\text { translator and dependency on } \\
\text { translator to translate } \\
\text { 'correctly and meaningfully' } \\
\text { and to facilitate interactions } \\
\text { during the training workshop. } \\
\text { Searched for TM examples } \\
\text { from clients to provide }\end{array}$ & $\begin{array}{l}\text { Liaised with CEO and } \\
\text { company; took on role as } \\
\text { translators, cultural sense- } \\
\text { maker, including political } \\
\text { aspects to shape views and } \\
\text { opinions, to create } \\
\text { commitment to a deeper } \\
\text { reaching modernising purpose } \\
\text { of the intervention. }\end{array}$ \\
\hline
\end{tabular}




\begin{tabular}{|l|l|l|}
\hline & $\begin{array}{l}\text { meaningful engagement. } \\
\text { Awareness of political } \\
\text { constellations of some of the } \\
\text { workshop participants; } \\
\text { stronger focus on } \\
\text { micropolitics }\end{array}$ & $\begin{array}{l}\text { Views his role as entailing } \\
\text { translation, knowledge } \\
\text { interpretation and creative } \\
\text { interpretation of what the } \\
\text { Consultant says. }\end{array}$ \\
\hline $\begin{array}{l}\text { Who has the } \\
\text { Floor? }\end{array}$ & $\begin{array}{l}\text { Commented on how her } \\
\text { explanations and comments, } \\
\text { which may take no more than } \\
\text { 30 seconds, took ages to } \\
\text { translate and created a degree } \\
\text { of concern about their } \\
\text { respective roles and inputs. }\end{array}$ & $\begin{array}{l}\text { Commented on the need to } \\
\text { explain, even make up } \\
\text { examples to further } \\
\text { intelligibility of concept and } \\
\text { ideas and to counteract any } \\
\text { assumptions that resources are } \\
\text { wasted. }\end{array}$ \\
\hline
\end{tabular}


TABLE 3 UNTRANSLATABLES OR PROBLEMATIC WORDS AND CONCEPTS FROM EMPIRICAL STUDY

\begin{tabular}{|c|c|c|}
\hline $\begin{array}{l}\text { Examples for TMD as } \\
\text { used before and during } \\
\text { training workshop }\end{array}$ & Slovak Translation & Comment by Translator \\
\hline $\begin{array}{l}\text { War for Talent as root } \\
\text { metaphor }\end{array}$ & $\begin{array}{l}\text { After machine translation } \\
=\text { koren = root of } \\
\text { plants/trees metaphor; } \\
\text { points to the importance } \\
\text { of subject and context- } \\
\text { specific knowledge. }\end{array}$ & $\begin{array}{l}\text { Neither machine nor } \\
\text { professional translators } \\
\text { have the knowledge base } \\
\text { to detect metaphorical } \\
\text { language. Slovak is a } \\
\text { literal language; } \\
\text { communication is more } \\
\text { direct. }\end{array}$ \\
\hline $\begin{array}{l}\text { Leadership; leadership } \\
\text { development; training, } \\
\text { mentoring }\end{array}$ & Often used as loan word. & $\begin{array}{l}\text { Difficult to translate, there } \\
\text { is no direct equivalent. } \\
\text { Meaning of leadership is } \\
\text { very different; it means } \\
\text { the boss, it means } \\
\text { hierarchy, it does not } \\
\text { mean development and } \\
\text { mentoring. } \\
\text { Training in state owned } \\
\text { companies is traditionally } \\
\text { associated with being } \\
\text { 'ineffectual', 'waste of } \\
\text { resource; feathering one's } \\
\text { pocket; (This } \\
\text { understanding persists in } \\
\text { private companies led by } \\
\text { former "nomenclatura"). }\end{array}$ \\
\hline $\begin{array}{l}\text { Categories of leadership } \\
\text { and talent: leadership, } \\
\text { Key, Core, Periphery }\end{array}$ & $\begin{array}{l}\text { No direct translation is } \\
\text { possible; use of word } \\
\text { kluchove (means 'key'), } \\
\text { but its meaning is not } \\
\text { differentiated from core } \\
\text { or leadership; no clear } \\
\text { word exist to express this } \\
\text { differentiation or to } \\
\text { indicate the 'hierarchical' }\end{array}$ & $\begin{array}{l}\text { Much of the translation } \\
\text { work did relate to } \\
\text { explaining 'core and } \\
\text { periphery' in structural } \\
\text { terms first, before these } \\
\text { words could even be } \\
\text { explained in the context of } \\
\text { TM; from thereon he still } \\
\text { needed to use examples to }\end{array}$ \\
\hline
\end{tabular}




\begin{tabular}{|l|l|l|}
\hline & $\begin{array}{l}\text { relationship between this } \\
\text { category for talent. }\end{array}$ & $\begin{array}{l}\text { make it clear what 'core } \\
\text { talent' means if it sits in a } \\
\text { department as opposed to } \\
\text { being located in the } \\
\text { Senior Management } \\
\text { Group. }\end{array}$ \\
\hline $\begin{array}{l}\text { Target Value } \\
\text { Propositions }\end{array}$ & $\begin{array}{l}\text { No direct translation is } \\
\text { possible; the meaning is } \\
\text { quite unclear; the } \\
\text { meaning in English is } \\
\text { unclear, too. }\end{array}$ & $\begin{array}{l}\text { Translator used the } \\
\text { English words, but spend } \\
\text { a long time trying to } \\
\text { explain what is meant by } \\
\text { this 'composite noun' and } \\
\text { explained its meanings by } \\
\text { making up example of } \\
\text { how a Head of } \\
\text { Department may } \\
\text { understand this term.... } \\
\text { this then lead to the need } \\
\text { for further explanations. }\end{array}$ \\
\hline $\begin{array}{l}\text { Equitable Assessment } \\
\text { Criteria }\end{array}$ & $\begin{array}{l}\text { No direct translation is } \\
\text { possible }\end{array}$ & $\begin{array}{l}\text { Equitable evokes a strong } \\
\text { sense of justice, a higher } \\
\text { morality and authority in a } \\
\text { Slovak mind; in a English } \\
\text { mind it evokes notion of } \\
\text { having to be fair and } \\
\text { transparent because of } \\
\text { rules. }\end{array}$ \\
\hline
\end{tabular}

